\title{
Executive Functions in Parkinson's Disease
}

\author{
Tainá Rossi ${ }^{1}$ \\ Mariane Bernardi Trevisol ${ }^{1}$ \\ Daiane Santos de Oliveira ${ }^{2}$ \\ Daiana Meregalli Schütr? \\ Manuela Polidoro Lima ${ }^{3}$ \\ Tatiana Quarti Irigaray ${ }^{3}$ \\ Camila Rosa de Oliveira ${ }^{1}$ \\ Luis Henrique Paloski ${ }^{1}$ \\ ${ }^{1}$ Faculdade Meridional (IMED), Passo Fundo, Rio Grande do Sul, Brasil \\ ${ }^{2}$ Centro Universitário Metodista (IPA), Porto Alegre, Rio Grande do Sul, Brasil \\ ${ }^{3}$ Pontifícia Universidade Católica do Rio Grande do Sul (PUCRS), Porto Alegre, Rio Grande do Sul, Brasil
}

\begin{abstract}
The objective of this study was to investigate executive functions (EFs) in older adults with Parkinson's disease (PD). It was a cross-sectional and comparative study, composed of 62 participants divided into PD group $\left(n=31 ; M_{\text {age }}=75.26 ; S D_{\text {age }}=7.26\right)$ and control group $\left(n=31 ; M_{\text {age }}=74.03 ; S D_{\text {age }}=6.95\right)$, aged 61 to 93 years, recruited for convenience in 5 cities in the state of Rio Grande do Sul. The instruments used were a sociodemographic data questionnaire; MMSE; GDS-15; BIS-11; verbal fluency tasks (FAS and animals), DEX; WCST-64 and FDT. Descriptive analyzes and Student's t and Chi-square tests were used. The PD group had a lower performance in the WCST-64 and FDT tests compared to controls, indicating worse performance in tasks that required reasoning, cognitive flexibility and processing speed, in addition, showed difficulties in performing tasks that require $\mathrm{EF}(\mathrm{DEX})$.

Keywords: cognition; neuropsychology; aging; problem solving; neuropsychological assessment.
\end{abstract}

Funções executivas na Doença de Parkinson

\section{Resumo}

O objetivo foi investigar as funções executivas (FE) em idosos com Doença de Parkinson (DP). Estudo transversal e comparativo, composto por 62 participantes, $50 \%$ do sexo feminino, recrutados por conveniência em cinco cidades do estado do Rio Grande do Sul, e divididos em dois grupos: $\operatorname{com} \mathrm{DP}\left(n=31 ; \mathrm{M}_{\text {idade }}=75,26 ; D P_{\text {idade }}=7,26\right)$ e grupo controle $\left(n=31 ; M_{\text {idade }}=\right.$ 74,03; $\left.D P_{\text {idade }}=6,95\right)$, com idade entre 61 e 93 anos. Os instrumentos utilizados foram: questionário de dados sociodemográficos, MEEM; GDS-15; BIS-11; tarefas de fluência verbal (FAS e animais); DEX; WCST-64 e FDT. Foram utilizadas análises descritivas e os testes $t$ de Student e Qui-quadrado. O grupo com DP teve desempenho inferior nos testes WCST-64 e FDT em comparação aos controles, indicando pior desempenho nas tarefas que exigiam raciocínio, flexibilidade cognitiva e velocidade de processamento, além disso, mostraram dificuldades ao realizar tarefas que demandam FE (DEX).

Palavras-chave: cognição, neuropsicologia, envelhecimento, solução de problemas, avaliação neuropsicológica.

\section{Funciones ejecutivas en la enfermedad de Parkinson}

\section{Resumen}

El objetivo de este trabajo fue investigar las funciones ejecutivas (FE) en ancianos con enfermedad de Parkinson (EP). Se trató de un estudio transversal y comparativo, compuesto por 62 participantes, $50 \%$ mujeres, reclutados por conveniencia en cinco ciudades de la provincia de Rio Grande do Sul, y divididos en dos grupos: con EP $\left(n=31 ; M_{\text {edad }}=75,26 ; D S_{\text {edad }}=7,26\right)$ y grupo control $\left(n=31 ; M_{\text {edad }}=74,03 ; D S_{\text {edad }}=6,95\right)$. Fueron usados cuestionarios de datos sociodemográficos, MEEM, GDS-15; BIS11; tareas de fluencia verbal (FAS y animales), DEX; WCST-64 y FDT. Se realizaron análisis descriptivos, prueba t de Student y chi-cuadrado. El grupo EP tuvo un rendimiento más bajo en las pruebas WCST-64 y FDT en comparación con el grupo control, lo que indica un peor rendimiento en tareas que requerían razonamiento, flexibilidad cognitiva y velocidad de procesamiento, además, mostró dificultades para realizar tareas que demandan FE (DEX).

Palabras clave: cognición; neuropsicología; envejecimiento; solución de problemas; evaluación neuropsicológica.

\section{Introduction}

Parkinson's disease (PD) is the second most common neurodegenerative disease in the world
(Delamarre \& Meissner, 2017; Poewe et al., 2017; Surmeier, Obeso \& Halliday, 2017). The evolution of PD symptoms is generally slow and progressive (Neri-Nani, 2017; Hess, \& Hallett, 2017). It is estimated that 5.2 
million individuals have PD in the world population; in the Americas, the estimate is 1.2 million individuals (World Health Organization [WHO], 2004). In Brazil, a study conducted in the municipality of Bambuí, state of Minas Gerais, indicated an estimate of $3.3 \%$ of PD cases in the city's population (Barbosa et al., 2006). Moreover, in 2030 these data may double, due to the increasing aging of the population (Dorsey et al., 2007; Faria, Lima, \& Silva, 2019).

The diagnosis of PD is clinical, and the main motor symptoms involve bradykinesia, tremor at rest, stiffness, postural changes, and changes in gait (slowness) (Surmeier et al., 2017; Neri-Nani, 2017). In addition to motor symptoms, changes in cognitive functions are very common (Galhardo, Amaral, \& Vieira, 2009) and cognitive damage may precede motor symptoms (Aarsland et al., 2017; Fengler et al., 2017; Schapira, Chaudhuri, \& Jenner, 2017).

Impairments in executive functions $(\mathrm{EFs})$ in PD are present in most cases and can become more severe during the course of the disease, contributing to the development of dementia (Mckinlay, Grace, Dalrymple-Alford, \& Roger, 2010; Pedersen, Larsen, Tysnes, \& Alves, 2017). EFs are skills that drive cognitive, emotional, and behavioral functioning, associated with the ability to adapt to new circumstances (Diamond, 2013; Macuglia et al., 2015). EFs are vulnerable to the aging process and involve complex processes that manage behaviors, such as planning, inhibition, decision-making, working memory, mental monitoring, organization, and processing speed (Diamond, 2013; Lopes, Bastos, \& Argimon, 2017; Tirapu-Ustárroz, Cordero-Andrés, Luna-Lario, \& Hernáez-Goñi, 2017). Therefore, deficits found in these functions are linked to damage in the prefrontal area of the brain (Delgado-Mejía \& Etchepareborda, 2013; Otero \& Barker, 2014; Zgaljardic et al., 2006). Changes in frontal functions, especially in EFs, are frequent in people with PD and these impairments differ from those usually arising from the aging process (Gruszka, Hampshire, Barker, \& Owen, 2017). This is because $\mathrm{PD}$ is the consequence of the death of neurons that produce dopamine, a brain substance that functions as a neurotransmitter in the central nervous system (Souza et al., 2011).

A systematic review sought to identify the neuropsychological profile of PD patients with mild cognitive impairment (MCI). Following refinement, 4 articles were included in the research, after consulting the MedLine and PsycInfo databases from 2012 to 2019. The results indicated higher levels of damage and frequency of impairment in EFs in people with PD and MCI, and less frequency but signs of impairment in learning and verbal and visuospatial memory (Rodrigues, Silva, Andrade, \& Calvo, 2019).

Studies related to neurodegenerative diseases are necessary due to the increasing aging of the population. Research on PD and EFs are relevant to verify the cognitive functioning of individuals with this disease to organize therapeutic strategies such as stimulation and cognitive training that can help in the quality of life of this population. Furthermore, it is possible to verify that therapeutic strategies for cognitive decline in PD are less developed than those for motor symptoms, whether pharmacological or nonpharmacological. (Dupouy et al., 2017; O'Callaghan \& Lewis, 2017; Mahajan, Deal, \& Carlson, 2017). Therefore, this study aimed to investigate changes in EFs of aged adults with PD.

\section{Method}

\section{Study Design}

Cross-sectional and comparative study.

\section{Participants}

A total of 62 older adults participated in this study. The age of the sample ranged from 61 to 93 years, 50\% were women $(\mathrm{n}=31)$, recruited for convenience and by the snowball technique. Among the participants, 31 composed the clinical group (PD) $\left(\mathrm{M}_{\text {age }}=75.26 ; \mathrm{SD}_{\text {agc }}\right.$ $\left.=7.26 ; \mathrm{M}_{\text {schooling }}=7.23 ; \mathrm{SD}_{\text {schooling }}=6.62\right)$ and 31 the control group $\left(\mathrm{M}_{\text {age }}=74.03 ; \mathrm{SD}_{\text {age }}=6,95 ; \mathrm{M}_{\text {schooling }}=\right.$ 6.97; $\left.\mathrm{SD}_{\text {schooling }}=5.62\right)$. There was no statistically significant difference between the groups regarding age $[F(1.60)=0.02 ; \mathrm{p}=0.50]$ and schooling $[\mathrm{F}(1.60)=$ $0.32 ; \mathrm{p}=0.86]$.

The inclusion criteria were: 1) age equal to or greater than 60 years; 2) diagnosis of PD (for the group of older adults with PD); and 3) literacy. The exclusion criteria were: 1) score suggestive of cognitive decline assessed by the Mini Mental State Examination (MMSE), and 2) primary sensory changes not corrected at the time of assessment (wearing glasses or hearing aid, for example). The sample size was calculated in the Winpeppi for Windows (Abramson, 2011) and estimated from the level of significance of $5 \%$ and power of $80 \%$, based on the results of Zgaljardic et al. (2006), which suggested 66 participants $(n=33$ for the PD group and $n=33$ for the control group). 
The sample was recruited for convenience. People in the PD group were included in the clinical group when the formal diagnosis of PD was confirmed by a medical report or medication used. A total of 83 aged adults with confirmed PD were invited, but only 31 completed the survey. Of these, one did not complete the withdrawal testing protocol, and 51 had a suggestive score for cognitive decline in the MMSE or were at an advanced stage of PD when in contact with the evaluators (such as bedridden, disorganized speech, and hallucinations).

\section{Instruments}

Sociodemographic data questionnaire: Composed of questions that assessed age, sex, education, marital status, subjective health perception, socioeconomic level, history of psychiatric disorders or clinical pathologies diagnosed by a doctor, as well as medications used.

Mini Mental State Examination - MMSE (adapted by Chaves \& Izquierdo, 1992): instrument for screening and assessing cognitive functions in aging adults with suspected dementia, with a Cronbach's Alpha of 0.79, indicating good reliability (Santos, Cerchiari, Alvarenga, Faccenda, \& Oliveira, 2010). The cutoff points used in this study were those suggested by Kochhann, Varela, Lisbon, and Chaves (2010) for aging adults in southern Brazil $(\geq 22$ points for 1-5 years of study, $\geq 23$ points for $6-11$, and $\geq 24$ for 12 or more years of schooling).

Geriatric Depression Scale, reduced version - GDS-15 (adapted by Almeida \& Almeida, 1999): Assists in tracking depressive symptoms in aging adults. It consists of 15 binary questions (yes and no) that indicate the occurrence of symptoms. The cutoff points used were those suggested by Pinho, Custódio, Makdisse, and Carvalho (2010), with $\leq 5$ points for the absence of depressive symptoms and $\geq 6$ points for the presence of depressive symptoms. In its Brazilian version (Almeida \& Almeida, 1999), the GDS-15 presented Cronbach's alpha equivalent to 0.81 , which suggests an adequate internal consistency index.

Semantic ('animals') and phonemic (FAS) verbal fluency tasks (Strauss, Sherman, \& Spreen, 2006): Both tasks assess aspects of language and executive functions (Whiteside et al., 2016). The administration of the tests consists of evoking as many words as possible that start with a certain letter (F, A and S), and the name of as many species of animals as possible within $1 \mathrm{~min}$. The punctuation refers to the number of words evoked correctly, that is, that are not repeated words and/or that did not start with the required letter. Both tasks have validity evidence based on external variables, mainly with other cognitive instruments (Shao, Janse, Visser, \& Meyer, 2014) and reference standards for aging adults developed by Esteves et al. (2015).

Wisconsin Card Sorting Test, reduced version- WCST-64 (Kongs, Thompson, Iverson, \& Heaton, 2000): Assesses cognitive flexibility, abstract reasoning, inhibition, and the ability to generate problem-solving strategies (Trentini, Argimon, Oliveira, \& Werlang, 2010). The respondent is asked to sort cards from a deck with other key cards according to criteria that are not explicit to him or her. The WCST-64 already presents normative data for Brazil (Esteves, 2015) and also evidence of validity based on external variables in comparison of performance between aging adults with and without depressive symptoms, and with and without mild cognitive decline (Esteves et al., 2018; Esteves, Oliveira, Irigaray, \& Argimon, 2016).

Five Digit Test- FDT (adapted by Paula $\&$ Malloy-Diniz, 2015). It assesses the speed and efficiency of cognitive processing, the consistency of focused attention and the progressive automation of the task (Campos, Silva, Florêncio, \& Paula, 2016; Sedó, Paula, \& Malloy-Diniz, 2015). The FDT has 4 steps: reading, counting, choosing, and switching. The reliability of the test was achieved from the analysis of internal consistency for the population of Brazilian adults, who composed the normative reference data, ranging from 0.70 (Cronbach's alpha of two halves) to 0.95 (Guttman) (Paula \& Malloy-Diniz, 2015).

Barratt's Impulsiveness Scale - BIS-11 (adapted by Malloy-Diniz, et al., 2010). It assesses impulsiveness according to behaviors that tend to be stable over time, such as inhibitory control and lack of planning. It presents Cronbach's alpha of 0.85 (Vasconcelos \& Malloy-Diniz, 2016).

Dysexecutive Questionnaire - DEX, (Wilson, Alderman, Burgess, Emslie, \& Evans, 1996). The DEX is part of the Behavioral Assessment of the Dysexecutive Syndrome (BADS) ecological battery (Macuglia, Almeida, Santos, \& Giacomoni, 2016; Wilson et al., 1996). It evaluates executive dysfunctions using a questionnaire answered by the patient or an informant, using a Likert scale of behaviors. In its Brazilian version (Macuglia et al., 2016), the DEX demonstrated preliminary evidence of content validity that ranged from 0.92 to 0.94 , which are considered high rates. 


\section{Procedures}

Two psychologists previously trained to administer and correct the instruments conducted the assessment. The control group was gathered after the PD group collection was completed. At this stage, people with the same characteristics as the clinical group (such as sex, age, and schooling [with a range of 2 years more to 2 years less]) but without a diagnosis of neurological disease were invited to participate. In this group, only 1 person invited did not participate for being illiterate. Individuals who agreed to participate signed a Free and Informed Consent Form, and responded to the instruments individually, in a single session, in approximately 90 minutes. The research project for this study was approved by a Research Ethics Committee (CAAE: 73088817.2.0000.5319), respecting all guidelines related to studies with human beings.

\section{Data analysis}

Data analyses were performed using SPSS, version 23 for Windows. The data distribution was verified using the Kolmogorov-Smirnov test (whose values are equal to or above 0.05 of normal distribution). Descriptive statistics were used and the Student's $t$ test was used for independent samples and the Chi-square was applied for comparison between the groups. Significance was set at $\mathrm{p}<0.05$.

\section{Results}

Data collection took place in August and September of 2017, in 5 cities in the state of Rio Grande do Sul. The comparison between the sociodemographic characteristics of the groups is shown in Table 1. The groups did not differ regarding sex, socioeconomic level, and marital status; however, there was a higher prevalence of subjective perception of general health assessed as bad/very bad in the PD group.

The PD group obtained a significantly higher score on GDS-15 compared to the control group $\left[\mathrm{M}_{\mathrm{PD}}\right.$ = 3.23; $\mathrm{SD}_{\mathrm{PD}}=1.69 ; \mathrm{M}_{\text {Control }}=1,74 ; \mathrm{PD}_{\text {Control }}=1.37$; $\mathrm{F}(1.60)=0.773 ; \mathrm{p} \leq 0.001]$, although no differences

Table 1.

Sociodemographic Characteristics of the Clinical Group (DP) and the Control Group

\begin{tabular}{|c|c|c|c|c|}
\hline & $\begin{array}{c}\text { Clinical Group (DP) } \\
\quad(n=31)\end{array}$ & $\begin{array}{l}\text { Control Group } \\
\quad(n=31)\end{array}$ & \multirow[t]{2}{*}{$\chi^{2}$} & \multirow{2}{*}{$p$} \\
\hline & $n(\%)$ & $n(\%)$ & & \\
\hline \multicolumn{5}{|l|}{ Sex } \\
\hline Women & $15(48)$ & $16(48)$ & 0.065 & 0.799 \\
\hline Men & $16(52)$ & $15(52)$ & & \\
\hline \multicolumn{5}{|l|}{ Socioeconomic level } \\
\hline A & $3(10)$ & $4(13)$ & 1.124 & 0.771 \\
\hline $\mathrm{B}$ & $13(42)$ & $16(52)$ & & \\
\hline $\mathrm{C}$ & $14(45)$ & $10(32)$ & & \\
\hline $\mathrm{D}-\mathrm{E}$ & $1(3)$ & $1(3)$ & & \\
\hline \multicolumn{5}{|l|}{ Marital status } \\
\hline Married or living together & $17(55)$ & $19(62)$ & 3.425 & 0.331 \\
\hline Separated & $0(0)$ & $1(3)$ & & \\
\hline Widower & $10(32)$ & $10(32)$ & & \\
\hline Single & $4(13)$ & $1(3)$ & & \\
\hline \multicolumn{5}{|l|}{ Subjective perception of health } \\
\hline Terrible/Bad & $5(16)$ & $0(0)$ & 15.032 & $\leq 0.001$ \\
\hline Regular & $13(42)$ & $5(16)$ & & \\
\hline Good/Great & $13(42)$ & $26(84)$ & & \\
\hline
\end{tabular}

Note. The comparison between groups was performed using the Chi-square. 
were found between the groups in the MMSE scores $\left[\mathrm{M}_{\mathrm{PD}}=26.29 ; \mathrm{SD}_{\mathrm{PD}}=2.37 ; \mathrm{M}_{\text {Control }}=27.00 ; \mathrm{SD}_{\text {Control }}\right.$ $=2.38 ; F(1.60)=0.005 ; p=0.244]$. Regarding performance in EFs, Table 2 shows the comparison between the group with PD and controls in verbal fluency tasks, WCST-64, FDT, BIS-11, and DEX.

Aged adults in the clinical group (PD), compared to the control group, showed more perseverative errors, as well as a lower number of responses at the conceptual level and completed categories in the WCST-64. The clinical group (PD) also needed more time to respond to the FDT cards and expressed a higher number of complaints related to executive skills than aged adults in the control group. There were no significant differences in the other variables investigated.

\section{Discussion}

The main objective of this study was to investigate changes in EFs in aging adults with PD. The results show that the PD group performed worse than the control group in tasks that required reasoning, cognitive flexibility, and processing speed (WCST-64 and FDT). Aging adults with PD also reported greater difficulties in performing tasks that require EFs (DEX) than those in the control group. Cognitive symptoms are frequent in PD, mainly deficits and complaints in EF (Gruszka, Bor, Barker, Necka, \& Owen, 2016; Gruszka et al., 2017; Kudlicka, Clare, \& Hindle, 2011; Kudlicka, Hindle, \& Clare, 2017; Macuglia et al., 2015; Rodrigues et al., 2019; Sobreira et al., 2008; Vlagsma et al., 2017).

Table 2.

Comparison between the Clinical Group (PD) and the Control Group in Executive Functions

\begin{tabular}{|c|c|c|c|c|c|c|}
\hline & \multicolumn{2}{|c|}{$\begin{array}{c}\text { Clinical Group (PD) } \\
\qquad(n=31)\end{array}$} & \multicolumn{2}{|c|}{$\begin{array}{l}\text { Control Group } \\
\quad(n=31)\end{array}$} & \multirow[t]{2}{*}{$F$} & \multirow{2}{*}{$p$} \\
\hline & $M$ & $S D$ & $M$ & $S D$ & & \\
\hline Phonemic verbal fluency (FAS) & 19.52 & 10.12 & 24.23 & 10.52 & 0.021 & 0.077 \\
\hline Semantic verbal fluency (animals) & 12.26 & 3.33 & 13.74 & 4.46 & 1.755 & 0.143 \\
\hline \multicolumn{7}{|l|}{ WCST-64 } \\
\hline Persevering errors & 21.48 & 11.50 & 12.10 & 8.21 & 4.917 & $\leq 0.001$ \\
\hline Non-persevering errors & 9.06 & 7.89 & 8.32 & 3.62 & 7.053 & 0.637 \\
\hline Conceptual level responses & 23.97 & 14.31 & 37.58 & 10.40 & 5.825 & $\leq 0.001$ \\
\hline Number of categories & 1.32 & 1.19 & 2.48 & 1,06 & 0.184 & $\leq 0.001$ \\
\hline Failures in maintaining context & 0.74 & 1.06 & 0.81 & 1.05 & 0.035 & 0.811 \\
\hline \multicolumn{7}{|l|}{ FDT } \\
\hline Reading (time) & 55.55 & 25.77 & 39.87 & 15.00 & 4.115 & 0.005 \\
\hline Reading (errors) & 0.26 & 1.00 & 0.06 & 0.25 & 5.054 & 0.303 \\
\hline Score (time) & 54.19 & 25.23 & 40.10 & 13.07 & 4.274 & 0.008 \\
\hline Score (errors) & 0.90 & 3.10 & 0.10 & 0.30 & 5.380 & 0.160 \\
\hline Choosing (time) & 87.35 & 40.62 & 63.39 & 20.21 & 5.367 & 0.005 \\
\hline Choosing (errors) & 6.19 & 9.28 & 2.90 & 4.06 & 3.179 & 0.076 \\
\hline Switching (time) & 118.35 & 44.49 & 92.74 & 32.65 & 1.333 & 0.012 \\
\hline Switching (errors) & 8.29 & 7.95 & 6.16 & 4.45 & 1.584 & 0.198 \\
\hline Inhibition & 31.81 & 29.01 & 23.52 & 16.94 & 5.109 & 0.176 \\
\hline Flexibility & 62.81 & 39.96 & 52.87 & 29.32 & 2.031 & 0.269 \\
\hline BIS-11 & 53.94 & 8.48 & 50.87 & 6.63 & 0.374 & 0.118 \\
\hline DEX & 24.90 & 11.16 & 16.42 & 7.27 & 3.803 & $\leq 0.001$ \\
\hline
\end{tabular}

Note. The comparison between groups was performed using Student's t-test for independent samples. WCST-64 = Wisconsin Card Sorting Test reduced version; FDT $=$ Five Digit Test; BIS-11 = Barratt's Impulsiveness Scale; DEX = Dysexecutive Questionnaire. 
The results presented by WCST-64 related to cognitive flexibility, inhibition, and abstract reasoning in the group with PD indicated a higher incidence of persevering errors and a lower incidence of conceptual level responses and complete categories. These findings corroborate the results found by Sobreira et al. (2008) when analyzing the performance of groups of aging adults with PD. In another study, individuals with PD also completed fewer categories in the WCST test (Galtier, Nieto, Lorenzo, \& Barroso, 2017). It should be considered that with advanced age, the number of persevering errors made by aging adults increases, reducing, in turn, conceptual level responses and the number of categories completed in the WCST-64 (Esteves, 2015; Esteves et al., 2016).

In this study, participants with PD had more complaints related to thinking and dysexecutive behaviors, assessed by DEX. Researchers used the BADS to investigate EFs in $40 \mathrm{PD}$ patients and 30 healthy controls, and found significant impairments in the PD group not related to the time and severity of the disease (Macuglia et al., 2015). Vlagsma et al. (2017) found significant impairment in the EFs that negatively influenced the quality of life of 42 individuals with $\mathrm{PD}$, using the DEX questionnaire.

The results of this research did not differ between the groups (clinical and control) concerning the number of errors related to the speed of cognitive processing and focused attention assessed by the FDT. However, the clinical group needed more time to perform the tasks when compared to the control group. Although they did not use FDT as a measure for the evaluation of EFs, other studies found differences in the cognitive flexibility of aging adults with PD when compared to healthy aging people. The results of these studies, found by the Stroop test, showed low performance associated with the group of older people with PD (Sisto, Slonena, Okun, Bowers, \& Price, 2016; Vlagsma et al., 2017). Therefore, the longer time spent by the clinical group to perform the FDT suggests that older adults with PD have lower information processing speed when compared to the control group.

It is important to highlight the differences found in the GDS-15 between the groups, although it was not one of the main objectives of this study. The clinical group reported more complaints regarding depressive symptoms than the control group. Studies indicate that psychiatric symptoms are among the most important non-motor symptoms of PD (Thobois, Prange, Sgambato-Faure, Tremblay, \& Broussolle, 2017).
Depression in PD, associated with impairments in the dopamine neurotransmitter system (Schapira et al., 2017), is characterized by loss of dopaminergic neurons (Mahajan et al., 2017; Souza et al., 2011) and appears to be a consequence of PD ( $\mathrm{Zhu}$, Hilten, \& Marinus, 2016), fluctuating due to the emotional state of the patient with PD (Neri-Nani, 2017). Another hypothesis of the findings of this study is that depression may have influenced the poor performance of aging adults with PD. Studies indicate that depressive symptoms are related to worse performance in the WSCT-64 test (Esteves, 2015; Esteves et al., 2016), and melancholic depression is associated with poor performance in tasks involving EFs (Bosaipo, Foss, Young, \& Juruena, 2017).

In the present study, no statistically significant results were found concerning impulsiveness, lack of planning, and inhibitory control, assessed by the Barratt Impulsiveness Scale, or aspects of language and EFs assessed by verbal fluency tasks (FAS and animals). A study involving 43 participants with PD and 20 healthy controls found similar results in the semantic and phonological verbal fluency tests in both groups (Galtier et al., 2017). There is no consensus in the literature on impulsiveness and PD. Relationships between impulsiveness and cognitive functions were not observed in the research by Almeida and Hamdan (2019), in which 50 people diagnosed with PD were evaluated, using the Barratt scale. In contrast, impulsive and compulsive behaviors have been described as about three times more common in PD than in healthy individuals, and this behavior may be increased due to the side effect of using specific medications for the treatment of PD (Erga, Alves, Larsen, Tysnes, \& Pedersen, 2016). It should be noted that in this research the medications used by aging adults were not monitored.

It is important that the neuropsychological functioning of aging adults with PD be understood. The identification of symptoms and impairments caused by the disease helps in the planning of rehabilitation treatments and cognitive training, which seeks to delay the degenerative course of PD and provide a better quality of life for the aging adult affected by it. Regarding the limitations of the present study, we believe that the comorbidities presented by the participants may have influenced the results. Furthermore, it was not possible to control variables such as the use of benzodiazepine drugs and their effects on the participants' performance during the evaluation. We suggest that future research, such as longitudinal studies, seek to obtain more detailed information about the course of decline 
in EFs during the progression of PD to reformulate therapies and treatments suitable for this population.

\section{References}

Aarsland, D., Creese, B., Politis, M., Chaudhuri, K. R., Ffytche, D. H., Weintraub, D., \& Ballard, C. (2017). Cognitive decline in Parkinson Disease. Nature Reviews Neurology, 13(1), 217-231. doi:10.1038/ nrneurol.2017.27

Abramson, J. H. (2011). WINPEPI updated: Computer programs for epidemiologists, and their teaching potential. Epidemiologic Perspectives \& Innovations, 8, e1. doi:10.1186/1742-5573-8-1

Almeida, O. P., \& Almeida, S. A. (1999). Confiabilidade da versão brasileira da escala de depressão em geriatria (GDS) versão reduzida. Arquivos de Neuropsiquiatria, 57(2-B), 421-426. doi: 10.1590/ S0004-282X1999000300013

Almeida, B. de. A., \& Hamdan, A. C. (2019). Impulsiveness and executive functions in Parkinson's disease. Dementia e Neuropsychologia, 13(4), 410-414. doi: 10.1590/1980-57642018dn13-040007

Barbosa. M. T., Caramelli, P., Maia, D. P., Cunningham, M. C. Q., Guerra, H. L., Lima-Costa, M. F., \& Cardoso, F. (2006). Parkinsonism and Parkinson's Disease in the Elderly: A Community-Based Survey in Brazil (The Bambuí Study). Movement Disorders, 21(6), 800-808. doi: 10.1002/mds.20806

Bosaipo, N. B., Foss, M. P., Young, A. H., \& Juruena, M. F. (2017). Neuropsychological Changes in Melancholic and Atypical Depression: A Systematic Review. Neuroscience \& Biobehavioral Reviews, 73, 309-325. doi: 10.1016/j.neubiorev.2016.12.014

Campos, M. C., Silva, M. L. da., Florêncio, N. C., \& Paula, J. J. de. (2016). Confiabilidade do Teste dos Cinco Dígitos em adultos brasileiros. Jornal Brasileiro de Psiquiatria, 65(2), 135-139. doi: 10.1590/0047-2085000000114

Chaves, M. L., \& Izquierdo, I. (1992). Differential diagnosis between dementia and depression: A study of efficiency increment. Acta Neurologica Scandinavica, 85(6), 378-382. doi: 10.1111/j.1600-0404.1992. tb06032.x

Delamarre, A., \& Meissner, W. G. (2017). Epidemiology, environmental risk factors and genetics of
Parkinson's disease. La Presse Médicale, 46(2 Pt 1), 175-181. doi:10.1016/j.lpm.2017.01.001

Delgado-Mejía, I. D., \& Etchepareborda, M. C. (2013). Transtornos de las funciones ejecutivas. Diagnóstico y tratamiento. Revista Neurología, 57(1), 95-103. Recuperado de http://neurocognitiva. org/wp-content/uploads/2014/04/Delgado-Mejia-ID-2013-Trastornos-de-las-funciones-ejecutivas.-Diagno $\%$ CC $\% 81$ stico-y-tratamiento.pdf.

Diamond, A. (2013). Executive function. Anual Review of Psychology, 64, 135-168. doi: 10.1146/ annurev-psych-113011-143750

Dorsey, E. R., Constantinescu, R., Thompson, J. P., Biglan, K. M., Holloway, R. G., Kieburtz, K., ...Tanner, C. M. (2007). Projected number of people with Parkinson disease in the most populous nations, 2005 through 2030. Neurology, 68(5), 384 386. doi: 10.1212/01.wnl.0000247740.47667.03

Dupouy, J., Ory-Magne, F., Mekies, C., Rousseau, V., Puel, M., Rerat, K., ... \& Brefel-Courbon, C. (2017). Cognitive complaint in early Parkinson's disease: a pilot study. Acta Neurologica Scandinavica, 1-8. doi: 10.1111/ane.12808

Esteves, C. S. (2015). Avaliação das funções executivas em idosos: Evidências de validade convergente e dados normativos do teste Wisconsin de Classificação de cartas versão reduzida de 64 cartas para idosos. Tese de Doutorado, Pontífica Universidade Católica do Rio Grande do Sul, Porto Alegre, RS, Brasil. Recuperado de http://tede2.pucrs.br/tede2/handle/tede/6489

Esteves, C. S., Oliveira, C. R., Moret-Tatay, C., Navarro-Pardo, E., Carli, G. A. de., Silva, I. G., ... \& Argimon, I. I. de. L. (2015). Phonemic and Semantic Verbal Fluency Tasks: Normative Data for Elderly Brazilians. Psicologia Reflexão e Crítica, 28(2), 350-355. doi: 10.1590\1678-7153.201528215

Esteves, C. S., Oliveira, C. R., Gonzatti, V., Lima, M. P., Moret-Tatay, C., Argimon, I. I. L., \& Irigaray, T. Q. (2018). Desempenho de idosos com e sem declínio cognitivo leve na versão reduzida do teste WCST-6. Estudos Interdisciplinares em Psicologia, 9(3, Supl. 1), 149-164. Recuperado de: http://pepsic.bvsalud.org/scielo.php?script $=$ sci_ arttext\&pid=S2236-64072018000400010\&lng=pt $\&$ tlng=pt.

Esteves, C. S., Oliveira, C. R., Irigaray, T. Q., \& Argimon, I. I. L. (2016). 
Desempenho de idosos com e sem sintomas depressivos no WCST-64. Avaliação Psicológica, 15(1), 31-39. Recuperado de: http://pepsic.bvsalud. org/scielo.php?script $=$ sci_arttext\&pid $=$ S1677$-04712016000100005 \& \operatorname{lng}=$ pt\&tlng $=$

Faria, L. J. F. de, Lima, P. M. R., \& Silva, N. L. P. (2019). Resiliência familiar diante do diagnóstico da doença de Parkinson na velhice. Revista Pesquisas e Práticas Psicossociais, 14(1), 1-18. Recuperado de http:// www.seer.ufsj.edu.br/index.php/revista_ppp/ article/view/1875/2090

Fengler, S., Liepelt-Scarfone, I., Brockman, K., Schaffer, E., Berg, D., \& Kalbe, E. (2017). Cognitive changes in prodromal Parkinson's Disease: A review. Movement Disorders, O(0), 1-12. doi: 10.1002/mds.27135

Galhardo, M. M. de. A. M. C., Amaral, A. K. F. J., \& Vieira, A. C. C. (2009). Caracterização dos distúrbios cognitivos na doença de Parkinson. Revista CEFAC, 11(2), 251-257. doi: 10.1590/ S1516-18462009000600015

Galtier, I., Nieto, A., Lorenzo, J. N., \& Barroso, J. (2017). Mild cognitive impairment in Parkinson's disease: Clustering and switching analyses in Verbal Fluency Test. Journal of the International Neuropsychological Society, 23, 1-10. doi:10.1017/S1355617717000297

Gruszka, A., Bor, D., Barker, R. R., Necka, E., \& Owen, A. M. (2016). The role of executive processes in working memory deficits in Parkinson's Disease. Polish Psychological Bulletin 47(1), 123-130. doi: 10.1515/ppb-2016-0013

Gruszka, A., Hampshire, A., Barker, R. A., \& Owen, A. M. (2017). Normal aging and Parkinson's Disease are associated with the functional decline of distinct frontal-striatal circuits. Cortex, 93(2017), 178-192. doi: 10.1016/j.cortex.2017.05.020

Hess, C. W., \& Hallett, M. (2017). The phenomenology of Parkinson's Disease. Journal Seminars in Neurology, 37(2), 109-117. doi: 10.1055/s-0037-1601869.

Kochhann, R., Varela, J. S., Lisboa, C. S. de. M., \& Chaves, M. L. F. (2010). The Mini Mental State Examination: Review of cutoff points adjusted for schooling in a large Southern Brazilian sample. Dementia e Neuropsychologia, 4(1), 35-41. doi: 10.1590/ S1980-57642010DN40100006

Kongs, K. S., Thompson, L. L., Iverson, G. L., \& Heaton, R. K. (2000). Wisconsin card sorting test-64 card version (WCST-64). Psychological Assessment Resources: Odessa.

Kudlicka, A., Clare, L., \& Hindle, J. V. (2011). Executive functions in Parkinson's disease: systematic review and meta-analysis. Movement Disorders, 26(13), 23052315. doi: $10.1002 / \mathrm{mds} .23868$

Kudlicka, A., Hindle, J. V., \& Clare, L. (2017). Everyday functioning of people with Parkinson's disease and impairments in executive function: a qualitative investigation. Disability and Rehabilitation, 1-13. doi: 10.1080/09638288.2017.1334240

Lopes, R. M. F., Bastos, A. S., \& Argimon, I. I. de. L. (2017). Treino das funções executivas em idosos: Uma revisão sistemática da literatura. Panamerican Journal of Neuropsychology, 11(1), 11-29. Recuperado de http://www.cnps.cl/index.php/cnps/article/ view $/ 271$

Macuglia, G. R., Almeida, R. M. M. de., Santos, F. C., \& Giacomoni, C. H. (2016). Behavioural assessment of the Dysexecutive Syndrome (BADS): Adaptação e evidências de validade. Revista Psico USF, 21(2), 219-231. doi: 10.1590/1413-82712016210201

Macuglia, G. R., Rieder, C. R. de. M., Trentini, L. B., Filho, N. H., Moraes, A. L., \& Almeida, R. M. M. de. (2015). Comprometimento executivo nas fases leve à grave da Doença de Parkinson. Revista Psico, 46(2), 198-207. doi: 10.15448/1980-8623.2015.2.15236

Mahajan, A., Deal, J. A., \& Carlson, M. (2017). Interventions in Parkinson's disease: Role of executive function. Frontiers in bioscience, 22, 416-427. doi: $10.2741 / 4492$

Malloy-Diniz, L. F., Mattos, P., Leite, W. B., Abreu, N., Coutinho, G., Paula, J. J. de., Tavares, H., Vasconcelos, A. G., \& Fuentes, D. (2010). Tradução e adaptação cultural da Barrat Impulsiveness Scale (BIS-11) para aplicação em adultos brasileiros. Jornal Brasileiro de Psiquiatria, 59(2), 99-105. doi: 10.1590/S0047-20852010000200004

Mckinlay, A., Grace, R. C., Dalrymple-Alford, J. C., \& Roger, D. (2010). Characteristics of executive function impairment in Parkinson's disease patients without dementia. Journal of the International Neuropsychological Society, 16(1), 268 - 277. doi: 10.1017/ S1355617709991299

Neri-Nani, G. A. (2017). Síntomas motores de la enfermedad de Parkinson. Revista Neurología, Psico-USF, Bragança Paulista, v. 26, n. 3, p. 439-449, jul./set. 2021 
Neurocirugía y Psiquiatría, 45(2), 45-50. Recuperado de http://new.medigraphic.com/cgi-bin/resumen.cgi? IDARTICULO $=72277$

O'Callaghan, C., \& Lewis, S. J. G. (2017). Cognition in Parkinson's Disease. International Review of Neurobiology, 133, 557-583. doi:10.1016/bs.irn.2017.05.002

Otero, T. M., \& Barker, L. A. (2014). The frontal lobes and executive functioning. Handbook of executive functioning, 29-44. doi: 10.1007/978-1-4614-8106-5_3

Paula, J. J., \& Malloy-Diniz, L. F. (2015). Five Digit TestTeste dos Cinco Dígitos. São Paulo: Hogrefe.

Pedersen, K. F., Larsen, J. P., Tysnes, O. B., \& Alves, G. (2017). Natural course of mild cognitive impairment in Parkinson Disease. American Academy of Neurology, 88(21), 1-8. doi: 10.1212/ WNL.0000000000003634

Pinho, M. X., Custódio, O., Makdisse, M., \& Carvalho, A. C. C. (2010). Confiabilidade e validade da Escala de Depressão Geriátrica em idosos com Doença Arterial Coronariana. Artigos Brasileiros de Cardiologia, 94(5), 1-10. doi: 10.1590/ S0066-782X2010005000032

Poewe, W., Seppi, K., Tanner, C. M., Halliday, G. M., Brundin, P., Volkmann, J., ... \& Lang, A. E. (2017). Parkinson disease. Nature reviews Disease primers, 3, 17013. doi: $10.1038 /$ nrdp.2017.13

Rodrigues, R. M., Silva, J. S. C. da., Andrade, S. M. dos. S., \& Calvo, B. F. (2019). Perfil neuropsicológico de pacientes com comprometimento cognitivo leve por doença de Parkinson: uma revisão sistemática. Revista Neuropsicologia Latinoamericana, 11(2), 13-20. doi: $10.5579 / \mathrm{rnl} .2016 .0461$

Santos, C. S., Cerchiari, E. A. N., Alvarenga, M. R. M., Faccenda, O., \& Oliveira, M. A. de. C. (2010). Avaliação da confiabilidade do mini-exame do estado mental em idosos e associação com variáveis sociodemográficas. Cogitare Enfermagem, 15(3), 406412. doi:10.5380/ce.v15i3.18879

Schapira, A. H. V., Chaudhuri, K. R., \& Jenner, P. (2017). Non-motor features of Parkinson disease. Nature Reviews Neuroscience, 18(1), 435-450. doi: 10.1038/ nrn.2017.62

Sedó, M., Paula, J. J. de., \& Malloy-Diniz, L. F. (2015). FDT: Teste dos cinco dígitos. (1 ${ }^{\mathrm{a}} \mathrm{ed}$.). São Paulo, SP: Centro Editor de testes e pesquisa em Psicologia.
Shao, Z., Janse, E., Visser, K., \& Meyer, A. S. (2014). What do verbal fluency tasks measure? Predictors of verbal fluency performance in older adults. Frontiers in Psychology, 5, 772. doi: 10.3389/ fpsyg.2014.00772

Sisto, S. M., Slonena, E., Okun, M. S., Bowers, D., \& Price, C. C. (2016). Parkinson's Disease and the Stroop Color Word Test: Processing speed and interference algorithms. Journal The Clinical Neuropsychologist, 14(23), 1-14. doi: 10.1080/13854046.2016.1188989

Sobreira, E. S. T., Pena, M. C. S., Filho, J. H. S., Souza, C. P., Oliveira, G. N., Tumas, V., \& Vale, F. de. A. C. do. (2008). Executive cognitive tests for the evaluation of patients with Parkinson's disease. Dementia \& Neuropsychologia, 2(3), 206-210. doi: 10.1590/ S1980-57642009DN20300008

Souza, C. F. M., Almeida, H. C. P., Sousa, J. B., Costa, P. H., Silveira, Y. S. S., \& Bezerra, J. C. L. (2011). A Doença de Parkinson e o Processo de Envelhecimento Motor: Uma Revisão de Literatura. Revista Neurociencias, 19(4), 718-723. Recuperado de http:// revistaneurociencias.com.br/edicoes/2011/ RN1904/revisao\%2019\%2004/570\%20revisao. pdf

Surmeier, D. J., Obeso, J. A., \& Halliday, G. M. (2017). Selective neuronal vulnerability in Parkinson disease. Nature reviews Neuroscience, 18(2), 101-113. doi: $10.1038 /$ nrn.2016.178

Strauss, E., Sherman, E. M. S., \& Spreen, O. (2006). A compendium of neuropsychological tests. New York: Oxford University Press.

Tirapu-Ustárroz, J., Cordero-Andrés, P., Luna-Lario, P., \& Hernáez-Goñi, P. (2017). Propuesta de um modelo de funciones ejecutivas basado em análisis factoriales. Revista de Neurología, 64(2), 75-84. Recuperado de http://www.fundacionargibide.org/ imagenes/FE\%20ANALISIS\%20FACTORIAL. pdf

Thobois, S., Prange, S., Sgambato-Faure, V., Tremblay, L., \& Broussolle, E. (2017). Imaging the Etiology of apathy, anxiety, and depression in Parkinson's disease: implication for treatment. Current Neurology and Neuroscience Reports, 17(76), 1-8. doi: 10.1007/ s11910-017-0788-0

Trentini, C. M., Argimon, I. I. de. L., Oliveira, M. da. S., \& Werlang, B. G. (2010). Teste Wisconsin de 
Classificação de Cartas: Versão para Idosos. São Paulo, SP: Casa do Psicólogo.

Vasconcelos, A. G., \& Malloy-Diniz, L. F. (2016). Escala de BARRATT (BIS-11). In

C. Gorenstein, Y. P. Wang, \&amp; I. Hungerbühler (Eds.), Instrumentos de avaliação em saúde mental (pp. 312-216). Porto Alegre: Artmed.

Vlagsma, T.T., Koerts, J., Tucha, O., Dijkstra, H. T., Duits, A. A., Van-Laar, T., \& Spikman, J. M. (2017). Objective versus subjective measures of executive functions: Predictors of participation and quality of life in Parkinson's disease? Physical Medicine and Rehabilitation, 98(11), 2181-2187. doi: 10.1016/j. apmr.2017.03.016

Whiteside, D. M., Kealey, T., Semla, M., Luu, H., Rice, L., Basso, M. R., \& Roper, B. (2016). Verbal fluency: language or executive function measure? Applied Neuropsychology - Adult, 23(1), 29-34. doi: 10.1080/23279095.2015.1004574

Wilson, B. A., Alderman, N., Burgess, P. W., Emslie, H., \& Evans, J. J. (1996). The behavioural assessment of the dysexecutive syndrome. Bury St Edmunds: Thames Valley Company.

World Health Organization. (2004). Disease incidence, prevalence and disability. Recuperado de http:// www.who.int/healthinfo/global_burden_disease/ GBD_report_2004update_part3.pdf

Zgaljardic, D. J., Borod, J. C., Foldi, N. S., Mattis, P. J., Gordon, M. F., Feigin, A., \& Eidelberg, D. (2006). An examination of executive dysfunction associated with frontostriatal circuitry in Parkinson's Disease. Journal of Clinical and Experimental Neuropsychology, 28(7), 1127-1144. doi: 10.1080/13803390500246910

Zhu, K., Hilten, J. J. van., \& Marinus, J. (2016). Associated and predictive factors of depressive symptoms in patients with Parkinson's Disease. Journal of Neurology, 263(6), 1215-1225. doi: 10.1007/ s00415-016-8130-3

Recebido em: 14/06/2019

Reformulado em: 19/05/2020

Aprovado em: 01/09/2020

About the authors:

Tainá Rossi - Psychologist graduated at the Meridional School (IMED), Passo Fundo; Master's student at the Graduate Program in Psychology of the Pontifícia Universidade Católica do Rio Grande do Sul (PUCRS).

ORCID: https://orcid.org/0000-0002-4131-4247

E-mail: tainabrossi@gmail.com

Mariane Bernardi Trevisol - Psychologist graduated at IMED, Passo Fundo.

ORCID: https://orcid.org/0000-0001-7649-958X

E-mail:ma.dal.lagnol@hotmail.com

Daiane Santos de Oliveira - Psychologist graduated from the Centro Universitário Metodista (IPA), Porto Alegre; Master's student at the Graduate Program in Biomedical Gerontology of PUCRS.

ORCID: https://orcid.org/0000-0002-5116-4393

E-mail: daianehausen@gmail.com

Daiana Meregalli Schütz - Psychologist (PUCRS), Master in Psychology (CAPES/PUCRS), Post-graduated in Clinical Psychology (IFP) and Legal Psychology (CFP).

ORCID: https://orcid.org/0000-0002-9861-0063

E-mail:daischutz@gmail.com 
Manuela Polidoro Lima - Graduated in Psychology at the Universidade de Caxias do Sul (UCS), Post-graduated in Hospital Psychology and Neuropsychology and Master in Health Sciences (emphasis on Oncology) at the Graduate Program of the Hospital de Câncer de Barretos (Universidade Federal de São Carlos, SP). PhD in Clinical Psychology from PUCRS.

ORCID: https://orcid.org/0000-0002-9366-7829

E-mail:manuela.lima@acad.pucrs.br

Tatiana Quarti Irigaray - Psychologist graduated at the Universidade Federal do Rio Grande do Sul (UFRGS), Master and PhD in Biomedical Gerontology and Post-Doctorate in Psychology from PUCRS. Coordinator of the research group Rehabilitation Evaluation and Human Animal Interaction (ARIHA/PUCRS).

ORCID: https:// orcid.org/0000-0002-6824-5448

E-mail: tatiana.irigaray@pucrs.br

Camila Rosa de Oliveira - Post-Doctorate in Psychology from PUCRS. PhD in Biomedical Gerontology and Master in Psychology from PUCRS. Psychologist graduated at UFRGS. Full Professor of the Graduate Program in Psychology at IMED. Coordinator of the Research Group on Cognition, Emotion and Technologies in Neuropsychology and Health (NICOG-TEC).

ORCID: https://orcid.org/0000-0003-2115-604X

E-mail: oliveiracrd@gmail.com

Luis Henrique Paloski - Professor of Psychology at the School of Health of IMED. PhD in Clinical Psychology and Master in Clinical Psychology from PUCRS. Post-graduated in Public Health at the Universidade Norte do Paraná. Graduated in Psychology at the Universidade Regional Integrada do Alto Uruguai e das Missões - Frederico Westphalen Campus.

ORCID: https://orcid.org/0000-0001-6965-3139

E-mail: luishenriquepaloski@gmail.com

Contact:

Travessa Vileta, 54, ap. 301, Jardim Botânico

Porto Alegre-RS, Brasil

CEP: 90690-150 
